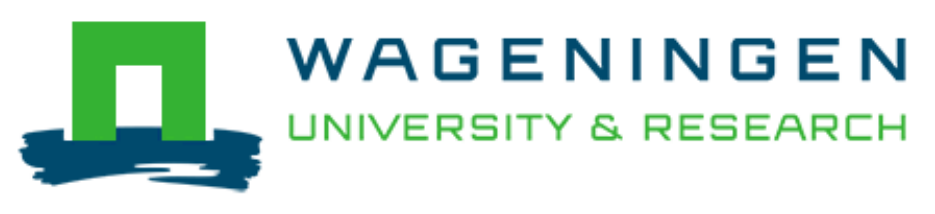

Liquefied natural gas production at Hammerfest: A transforming marine community

van Bets, L. K. J., van Tatenhove, J. P. M., \& Mol, A. P. J.

This article is made publically available in the institutional repository of Wageningen University and Research, under article $25 \mathrm{fa}$ of the Dutch Copyright Act, also known as the Amendment Taverne.

Article $25 \mathrm{fa}$ states that the author of a short scientific work funded either wholly or partially by Dutch public funds is entitled to make that work publicly available for no consideration following a reasonable period of time after the work was first published, provided that clear reference is made to the source of the first publication of the work.

For questions regarding the public availability of this article, please contact openscience.library@wur.nl.

Please cite this publication as follows:

van Bets, L. K. J., van Tatenhove, J. P. M., \& Mol, A. P. J. (2016). Liquefied natural gas production at Hammerfest: A transforming marine community. Marine Policy, 69, 52-61. DOI: $10.1016 /$ j.marpol.2016.03.020

You can download the published version at:

https://doi.org/10.1016/j.marpol.2016.03.020 


\title{
Liquefied natural gas production at Hammerfest: A transforming marine community
}

\author{
Linde K.J. van Bets*, Jan P.M. van Tatenhove, Arthur P.J. Mol \\ Environmental Policy Group, Wageningen University, PO Box 8130, 6700 EW Wageningen, The Netherlands
}

\section{A R T I C L E I N F O}

Article history:

Received 10 February 2016

Received in revised form

22 March 2016

Accepted 22 March 2016

Available online 9 April 2016

\section{Keywords:}

Coalitions

Marine community

Small Island Developing State

Sustainable development

Hammerfest

\begin{abstract}
A B S T R A C T
Global energy demand and scarce petroleum resources require communities to adapt to a rapidly changing Arctic environment, but as well to a transforming socio-economic environment instigated by oil and gas development. This is illustrated by liquefied natural gas production by Statoil at Hammerfest, which opened up the Barents Sea for oil and gas drilling. Although environmental organisations, Sámi indigenous people, fisheries and local inhabitants of Hammerfest try to strive for environmental and community development in relation to liquefied natural gas production by engaging in negotiations with Statoil and the Norwegian government, they are overshadowed by economic growth, implemented by a strong coalition between Statoil and the Norwegian State. Sustainable development of liquefied natural gas production is therefore constrained by centralized decision-making by the institutional coalition. Statoil's concessions on environmental and community development were rather based on cost-efficient and short-term means. This is strengthened by the fact that contact with stakeholders faded away once the social license to operate was achieved. This article will analyse why current governance of liquefied natural gas production at Hammerfest did not move beyond economic development.
\end{abstract}

(c) 2016 Elsevier Ltd. All rights reserved.

\section{Introduction}

The convergence of rapidly increasing global energy demands and climate change in the Arctic opens up possibilities for oil and gas companies. At the same time, they face unique challenges. The Arctic, despite moderating temperatures and retreating sea ice, remains a harsh environment. Human and environmental safety is difficult to ensure. The Arctic environment is fragile and recovers slowly after ecosystem damage [1,2]. Another challenge is that small, isolated (indigenous) communities, in for example Alaska, Canada, Russia, the Shetland Islands (United Kingdom (UK)) and Norway, which are often highly dependent on marine resources for subsistence, are confronted with large oil and gas companies. These communities, already exposed to a changing Arctic environment, are now affected by an external labour force, industrial development, energy politics and sudden wealth [3,4], but also with growing tension between these communities, the state and the oil and gas industry.

In Northern Alaska there is for over thirty years a structural conflict over offshore oil and gas development in the Chukchi and Beaufort Seas, between surface users (Inupiat subsistence

\footnotetext{
* Corresponding author.

E-mail address: linde.vanbets@wur.nl (L.K.J. van Bets).
}

hunters), subsurface owners (the state and federal governments that own the oil and gas rights), and the oil industry. While there are many opportunities for local involvement in offshore decision making, cultural factors, local capacity and competing interests compromise effective use of such opportunities [5,6]. Another example concerns oil and gas exploitation in Nunavut (Canada). Although Nunavut does not have any offshore jurisdiction, Inuit indigenous people rights are protected through various rules and organizations, such as the Inuit Circumpolar Council, the Canadian Constitution and settled land claim agreements which are treaty based like the Nunavut Land Claims Agreement [7]. Both in Alaska and Canada the exploitation of oil and gas reserves has led to the settlement of indigenous ownership claims. In Russia, on the other hand, resources have been extracted disregarding local land claims and involvement. However, the examples of the Yama-Nenets Autonomous Okrug and the neighbouring union Yerv symbolize a growing empowerment of indigenous communities in relation to oil and gas companies [3]. Finally, in 1975 Sullom Voe (Shetland Islands, UK) was identified as a location to provide pipeline terminal and support facilities for offshore oil and gas in the North Sea. After 30 years of experience, the Sullom Voe terminal has become a pioneering model of integrated coastal zone management based on adaptability and independence from government, industry and special interest groups [8].

This paper will look into one of such communities, 
Hammerfest's fishing community, near the Barents Sea, off the northernmost tip of Norway and neighbouring Russia. Hammerfest became the capital of Norway's new 'Arctic Energy Province' due to oil and gas discoveries pioneered by Statoil's liquefied natural gas (LNG) plant. During this development, Statoil faced, on the one hand, technological hurdles and opposition from environmentalists, sceptical fishermen and a wary local population. The plant introduced, on the other hand, socio-economic changes which were welcomed by Hammerfest's community. Finnmark County, where Hammerfest is located, is highly dependent on resources of the Barents Sea. Until recently this area was known best for out-migration and a declining fishing industry due to its isolated location and globalization of fisheries [9]. Due to the construction and putting into operation (in 2007) of the LNG plant Hammerfest experienced a population growth and a thriving economy [4]. Hence Hammerfest's community needs to adapt to a rapidly changing Arctic environment, but also to a new socioeconomic environment instigated by oil and gas developments. To adapt to such changes is particularly challenging for Hammerfest's community, which resembles characteristics of what is labelled a 'small island developing state': a rather isolated territory with abundant natural resources and limited governance capacity in terms of human, financial, information and other resources [10]. Such areas face challenges in resource management such as lack of knowledge, lack of resources and a scale mismatch between actors impacting natural resources and actors preventing/governing such impacts. Effective governance is crucial for maximizing benefits and minimizing negative impacts.

The aim of this paper is to analyze the introduction of LNG production in the community of Hammerfest and the enabling and constraining conditions of this community to govern environmental consequences of LNG production in Hammerfest. The central research question is: How is Hammerfest, as an example of a small island developing state type of community, affected by the introduction of a new activity, such as a new LNG plant? And in what way is such a community capable of preserving its vulnerable marine ecosystem in relation to environmental consequences of this new activity?

Section two will introduce the theoretical framework. Core concepts are marine community and the policy arrangements approach. Section three describes the methodology, while section four analyze and explains the transformation of Hammerfest's community around LNG production, based on empirical data from interviews. This section starts with the reconstruction of the marine community followed by the implications for sustainable

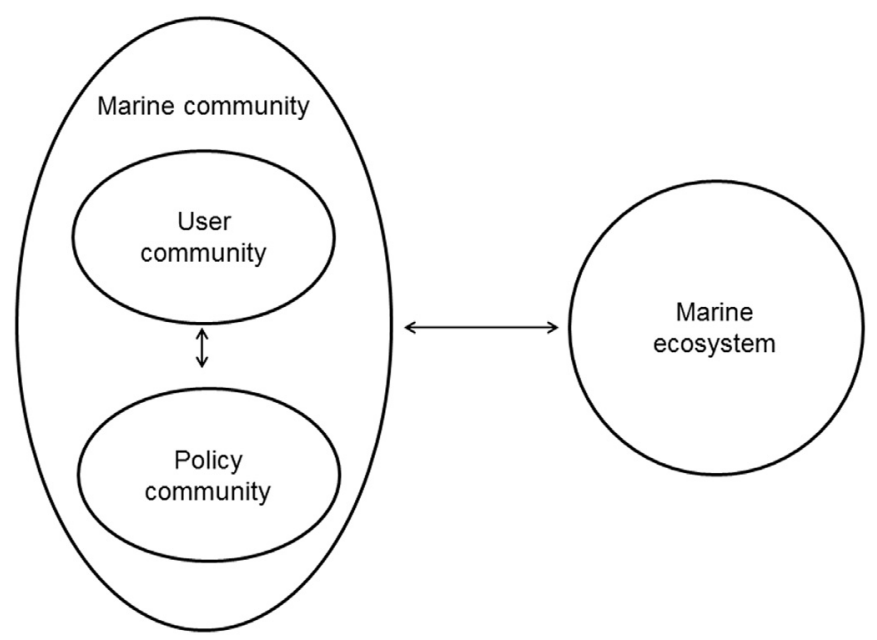

Fig. 1. The relation between marine communities and marine ecosystems. development of LNG production in Hammerfest. Section five presents the discussion and section six the conclusions and recommendations.

\section{Theoretical framework}

To analyze socio-economic and political dynamics around LNG production in Hammerfest in relation to a rapidly changing Arctic environment, the concept of marine community is introduced. A marine community is a community of socio-economic and policy actors and institutions organized around a certain maritime activity which influences or will be affected by the (marine) ecosystem in which the activity takes place. Analytically, in a marine community two interdependent communities can be distinguished: a user and a policy community, shown in Fig. 1. Both communities have a distinctive logic, rationality, purpose and institutional rules. A user community is a community of interdependent actors that executes and is affected by the maritime activity and which makes use of the goods and services marine ecosystems provide [11,12]. A policy community consists of actors that are part of (in) formal institutions and governance arrangements that regulate maritime activities to realize sustainable use and management of marine ecosystems [13-15].

To analyze the functioning and development of marine communities the dimensions of the policy arrangement approach are applied, such as actors and their coalitions, resources, rules of the game and discourses [22]. This paper focuses on the development and institutionalization of coalitions and how they make use of the other dimensions of the policy arrangement approach, in order to understand the enabling and constraining conditions for sustainable development of the marine community in Hammerfest. The formation of policy coalitions is analyzed from both a strategic and an institutional perspective. In general, marine communities consist of interdependent state, market, civil society and scientific actors (from different levels) who interact with each other in user and policy communities. The interdependency between actors is determined by their ability to possess, choose to share and mobilize resources, and to define and to apply rules of the user and policy community, based on their perceptions and discourses. Resources can vary from tangible resources like regulations, financial means and databases to less tangible, but equally important, resources like power, status, legitimacy, knowledge and information. Rules refer "to the rules of the game currently in operation, in terms of formal procedures of decision-making and implementation, as well as informal rules and routines of interaction [16]". Rules thus determine how decision-making takes place, who is involved and who has access to certain resources. Perceptions are definitions or images of reality used by actors to interpret and to evaluate their actions and those of others [17-20]. Based on these perceptions, "ensembles of ideas, concepts and categorisations are produced, reproduced and transformed in a particular set of practices and through which meaning is given to physical and social realities, the so called policy discourses [21]". Guided by policy discourses, actors will decide with whom they will form a policy coalition in which they share resources and strategies. As such these policy coalitions will identify similar goals and therefore engage in policy processes to achieve them. In this policy process some coalitions might support the dominant policy discourse or rules of the games, while others will challenge these [22].

To integrate LNG production in Hammerfest's marine community in a sustainable way, forms of governance need to be tailored and adapted to the (changing) characteristics of the marine community and marine ecosystem. Therefore this paper will analyze how the transformation of the marine community has enabled or 
constrained governance of LNG production in Hammerfest.

\section{Methodology}

To understand relationships, complexities and institutional settings within a marine community, a case study design was chosen. A case study allows the researcher to derive an in-depth understanding of the research object by looking at a range of factors, potential causal connections as well as how they change over time. In addition, this methodology is useful to address actors' motives, interpretations, constructions of reality and behavior $[23,24]$. Hammerfest was selected as case study because it is a symbolic push for Arctic oil and gas development as Statoil's LNG plant reversed the long-standing closure of the Barents Sea for oil and gas drilling [4]. Other interesting characteristics are coexistence with local fisheries and Sámi indigenous people. Furthermore Hammerfest shows different forms of cooperation between a large oil and gas company and a local municipality. Cooperation is for example initiated from Statoil's Corporate Social Responsibility strategy [25] which encompasses the idea that businesses have not only economic and legal obligations, but also ethical and philanthropic responsibilities to society which go beyond making profit for their shareholders [26]. This paper will investigate how forms of cooperation between different coalitions affect possibilities for sustainable development in Hammerfest.

Semi-structured interviews with key informants served to map the marine community structure and to identify how actors positioned themselves in coalitions in this community and which resources, rules, perceptions and discourses they used. Key informants represented national and local governmental authorities, oil and gas companies and their supply industry, environmental non-governmental organizations (NGOs), researchers and fishermen. Field work at Hammerfest was conducted for two weeks in October 2014. 14 interviews were conducted in total, of which nine with a single interviewee and five with multiple interviewees. Nine interviews were conducted face-to-face, four by Skype and two by videoconferencing. Before field work started seven appointments were already made with a selection of interviewees, based on their role in the marine community. Remaining interviewees resulted from a snowball sampling method influenced by the preselected interviewees. Information provided by interviewees was double checked by asking different interviewees the same information. All interviews were recorded with a voice recorder. Interviews were transcribed as soon as possible after the interview took place. Anonymity of the interviewees was guaranteed; therefore a coding system is used for referencing interviews in this article (see Table 1). Data analysis is based on triangulation of data from semi-structured interviews, literature review, policy document analysis and participatory observations by the researcher through labeling and coding with Atlas.ti.

Table 1

Coding overview interviewees.

\begin{tabular}{|c|c|}
\hline Coding & Interviews \\
\hline I-G-1 to 3 & $\begin{array}{l}\text { Interviews with government officials from } \\
\text { - National ministries } \\
\text { - State agencies } \\
\text { - Hammerfest Kommune }\end{array}$ \\
\hline I-M-1 to 5 & $\begin{array}{l}\text { Interviews with market parties from } \\
\text { - Oil and gas companies } \\
\text { - Fisheries } \\
\text { - Supply industry }\end{array}$ \\
\hline I-CS- 1 to 2 & Interviews with environmental non-governmental organizations \\
\hline I-R-1 to 4 & Interviews with national researcher institutes \\
\hline
\end{tabular}

\section{A transforming marine community on LNG production in Hammerfest}

Hammerfest is located in Finnmark (see Fig. 2), Norway's most fishery-dependent county, due to its high adjacency to resources in the Barents Sea, such as Atlantic cod and herring, and the significant amount of Russian landings of cod it receives. Traditionally, fishing villages along the coast of Finnmark are characterized by their scattered location, limited industrial base and great distances between populated areas. Large investments by the Norwegian government transformed the marine community in Finnmark from a fishing to a fish processing community in the 1970s.

Afterwards governmental interventions introduced a welfare policy in Finnmark which resulted in the public sector, followed by tourism. Nevertheless fisheries still faced resource and market crises in the 1980s and 1990s [9]. Currently local fishermen feel threatened by globalization of fisheries; in particular by industrial fisheries in southern Norway and Russia. As a result Hammerfest's population declined. Especially young people left due to lack of future perspective as fishing faired poorly and new business opportunities were stagnant [4,24,I-G-3]. Until 2002 Hammerfest's marine community was highly dependent on fisheries for its livelihood and local economy and consisted of a local user community of fishermen, local inhabitants and Sámi indigenous people and a local policy community with the municipality as central actor. This marine community resembles a one-sided, subsistencedriven, economy of small island developing states [28].

Because of the exploitation of oil and gas in the Barents Sea and the development of the LNG plant at Melkøya, Hammerfest transformed from a local marine fisheries community to a national (and even international) marine community, with the international petroleum industry at its centre. Melkøya is an island, just west of Hammerfest, which is connected to the mainland through a tunnel. The LNG plant processes gas from three offshore natural gas fields Snøhvit, Albatross and Askeladden in the Barents Sea, situated $140 \mathrm{~km}$ from Hammerfest. Those gas reserves were discovered between 1981 and 1984. Natural gas is distributed through a pipeline to the processing plant at Melkøya, where it is converted to LNG (shown in Fig. 3). In 2002 the construction was approved by the Norwegian government. Since August 2007 the plant is operational. Initially LNG would be shipped to the United States of America (USA). However, discoveries of huge amounts of shale gas transformed the USA from being dependent on import of oil and gas, to a self-producing country. Currently most LNG is transshipped to Europe, but the Asian demand is increasing rapidly [26, I-R-4]. This LNG plant is quite remarkable because of its scale and the technology it applies in the vulnerable Arctic environment. Gas extraction occurs without surface installations, because conversion takes place on shore. Instead of fixed or floating units, subsea production facilities stand at water depths of $250-345 \mathrm{~m}$ on the seabed. Seabed facilities are designed to be overtrawlable, so that both oil and gas industry and fisheries do not suffer from any damage by touching the seabed. To reduce emissions, the plant is designed to capture $\mathrm{CO}_{2}$ which is re-injected in the field [30].

Statoil's LNG plant near Hammerfest brought new economic perspectives to the region, and transformed the marine community. The next section will explain the changes in Hammerfest's marine community by analysing how institutional, strategic and oppositional coalitions affected the resources, rules and discourses of the user and policy community.

\subsection{Institutional coalition}

Since the establishment of Statoil as a state-owned company in 1972, the relation between the Norwegian State and Statoil can be 


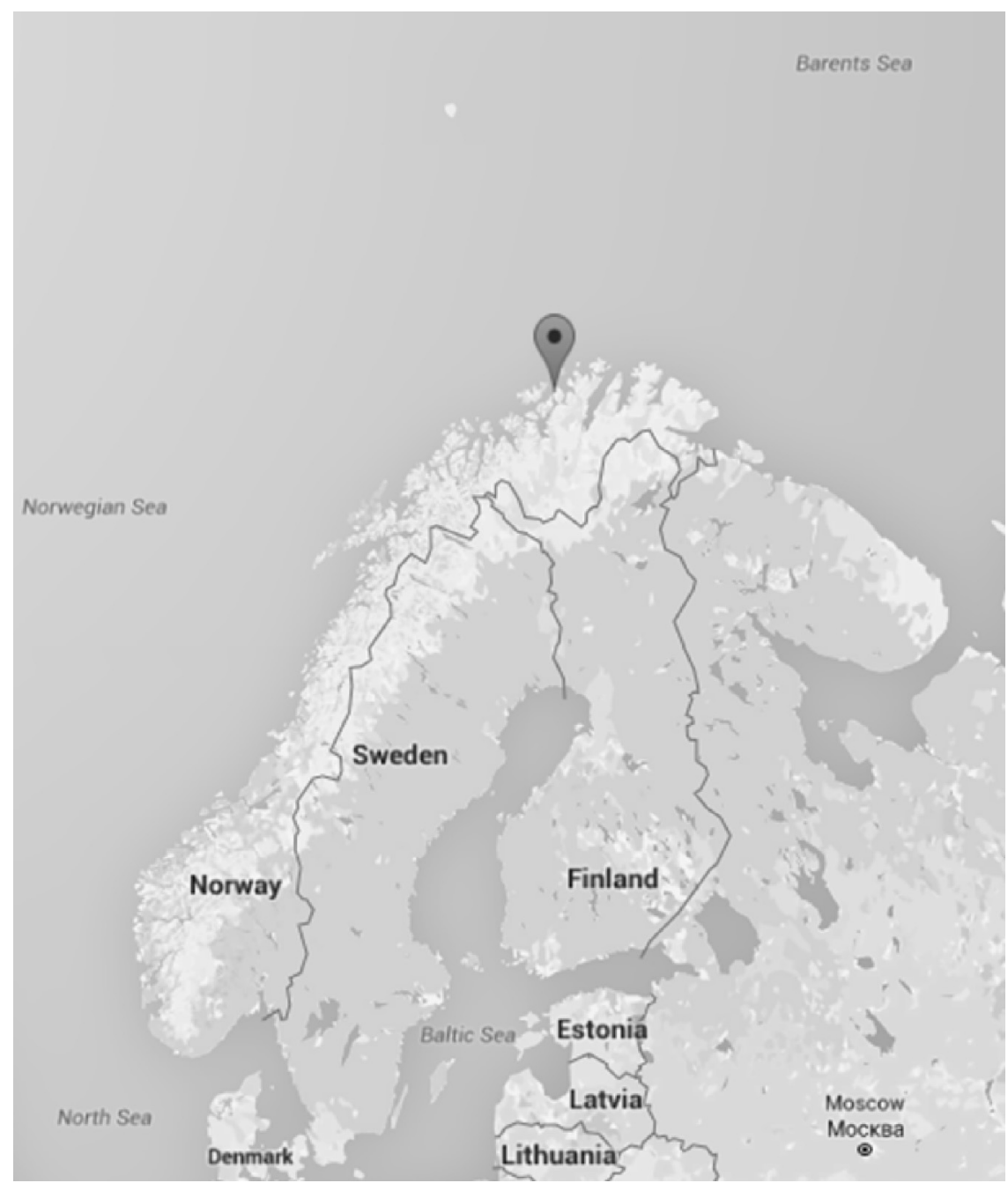

Fig. 2. The location of Hammerfest [45].

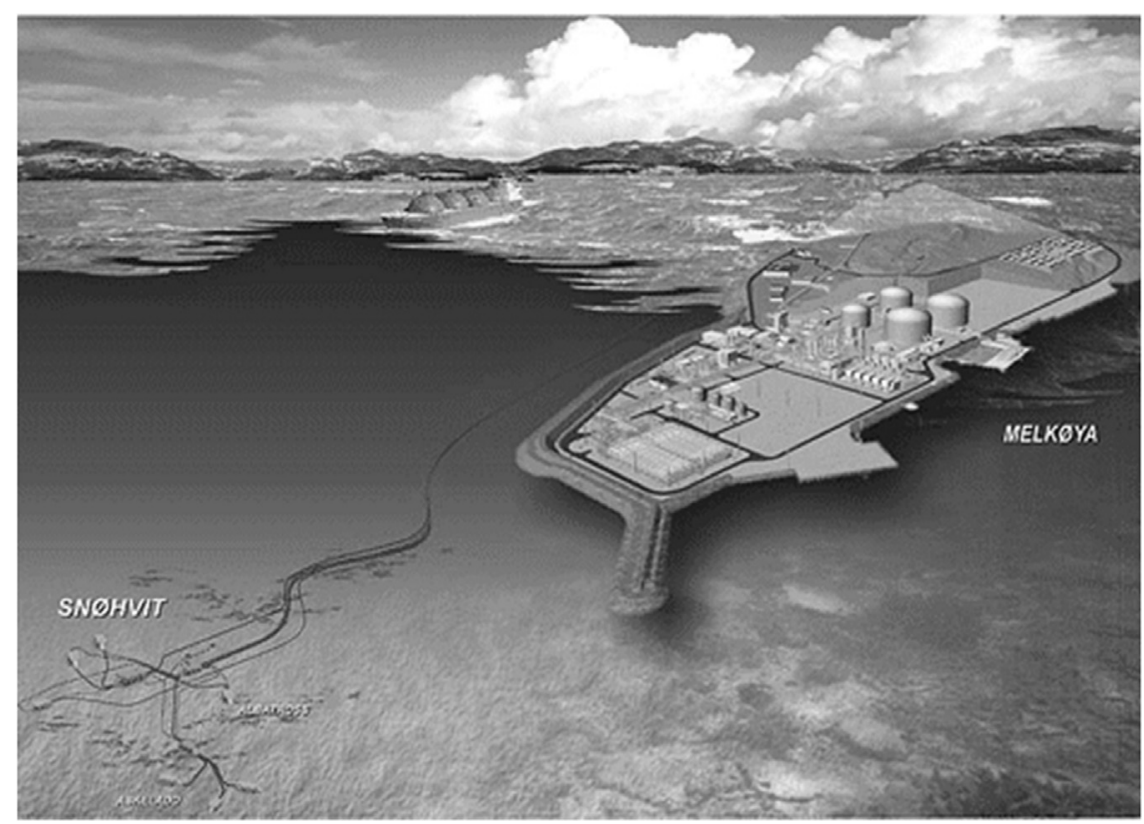

Fig. 3. Overview of the operation of the LNG plant [46] (approved by Statoil). 
characterized as an institutional coalition; i.e. a structural relationship based on formal rules that formalizes its interdependency through sharing of resources and discourses. Characteristic for this institutional coalition are its two faces: the first face is the state participant/user relation, the second face is the regulator/user relation.

Despite several changes, such as increased state participation in the 1980s and semi-privatization in the 2000s [4], the state participant/user relation between the Norwegian government and Statoil has been institutionalized during the last decades. ${ }^{1}$ This relation was further strengthened by initiatives of the Norwegian government, such as Norwegianization of the oil and gas industry, by giving preference to domestic oil companies and suppliers [31], the 'High North Strategy' of the Stoltenberg administration with a renewed interest in Finnmark's economic development, coupled with offshore oil and gas activities and cooperation with Russia [4] and Norway's tax efficient system which incentivizes oil and gas exploration. ${ }^{2}$

The second face of the institutional coalition represents the regulator/user relation. Besides participating in oil and gas activities, the Norwegian State is also responsible for regulating these activities. Since the 1970s Norway has moved towards a performance-based approach to supervise oil and gas activities, in which the state defines the performance that needs to be achieved, while the industry is free to decide how this will be done [32]. The Petroleum Act (1996) governs petroleum activities, under jurisdiction of the Ministry of Petroleum and Energy and its Petroleum Directorate. Before an area is opened up for oil and gas drilling, a strategic impact assessment is made and the public is consulted [33]. This is an important moment for other actors (like research institutes and NGOs) to question the nature and extent of proposed oil and gas activities in relation to social, economic and environmental effects (I-R-2;I-CS-1).

The two faces of the Norwegian government (as state participant and as regulator of oil and gas) could be conflicting. According to an NGO, their input is not taken into account and even overruled by the Norwegian government's face as state participant: "The Norwegian Polar Institute and the Environment Agency provide the same input as we do; it is not taken into account. In Norway the situation is, issuing a consequence analysis equals opening up the area for oil and gas activities (I-CS-2)". Once the area is opened, the most important resource for developing any oil and gas discovery is the Plan for Development and Operation (PDO) licensees have to submit. A PDO contains an account of economic, resource, technical, safety, commercial and environmental aspects, as well as information as to how a facility may be decommissioned and disposed of when the petroleum activities have ceased. The Ministry of Petroleum and Energy is authorized to approve a PDO. Because of the scale of Statoil's LNG plant approval of the Norwegian State was required [31, I-R-4]. In 2007 the LNG plant started to operate. The Environment Agency and the Petroleum Safety Authority monitor the environmental impact and safety of the plant. Statoil reports on compliance with the permits based on the 'internal control principle' (I-CS-1). As Statoil is in charge, they consult national research institutes to monitor the effects of the LNG plant on different parts of the environment (I-R-3). In case of non-compliance, Statoil has a notification duty. Afterwards agencies will set a deadline by which non-compliance should be solved. Results about monitoring and rule compliance are made publicly available by the agencies at stake (I-G-1; I-G-2; I-M-2; I-CS-1; I-R-

\footnotetext{
${ }^{1}$ Currently the Norwegian State has a direct ownership of $67 \%$ within Statoil, managed by the Ministry of Petroleum and Energy. Apart from a share within Statoil, state participation in Statoil's LNG project is even more prominent by the $30 \%$ share of the state-owned company Petoro [43].

$278 \%$ of the costs are reimbursed in the subsequent year [44].
}

1). These state agencies represent independently both faces of the Norwegian State in the institutional coalition. While the Ministry of Petroleum and its Petroleum Directorate represent state participation in Statoil's LNG plant, the Environment Agency and the Petroleum Safety Authority regulate this industry.

\subsection{Strategic coalitions}

The strong institutional coalition between the Norwegian State and Statoil changed the relations between the user and policy community in Hammerfest. Characteristic for Hammerfest's marine (fisheries) community is its isolation and lack of resources and knowledge to counterbalance the power of a multinational company like Statoil. "Oil and gas companies and the Ministries are the same people, they have the same interest; they have the license to operate (I-M-3)." The lack of trust in the Norwegian State's regulatory face versus its state participant face and the lack of an institutional coalition between Hammerfest municipality and the Norwegian State, forced local actors to define their position in relation to the institutional coalition. Two strategic coalitions emerged: one between Statoil and fisheries and one between Statoil, Hammerfest municipality and local inhabitants. Each of these strategic coalitions has its own resources, rules and discourses to achieve its objectives. Compared to the institutional coalition, these coalitions have a short-term and strategic character because actors try to pursue their interest by looking for actors with whom policy interpretations are shared and acceptable consensus can be reached, while disregarding actors with conflicting policy interpretations [22].

The formation of these coalitions is essential for acquiring a social license to operate (SLO) for the LNG plant. The concept of a SLO emerged in the late 1990s, predominantly in the mining industry [34]. Currently the concept is used in a variety of contexts ranging from business, academia, and consultants to media. A SLO is "the ongoing acceptance and approval of the activities of an industry by local communities and other stakeholders [35]". Although it is difficult to measure whether or not a SLO has been granted, Thomson and Boutilier [36] introduce four concepts to understand how a company like Statoil can obtain and maintain its SLO. First, economic legitimacy is determined by the level of local benefits provided by the activity at stake. Second, interactional trust is based on "the perception that the company listens, responds, keeps promise, engages in mutual dialogue and exhibits reciprocity in its interactions [36]". Thirdly, institutionalized trust requires stakeholders to perceive that the relationships between their institutions and the company are based on mutual trust with respect for each other's interests. Fourth, socio-political legitimacy is required, and is characterized by fairness, meeting expectations and contributing to the well-being of a region or a country [36].

\subsubsection{Strategic coalition: Statoil and fisheries}

Interaction between Statoil and fishermen was triggered by fishermen's scepticism about the pipeline path connecting offshore gas fields to the LNG plant, released in the construction plan in 2002. The pipeline crossed important fishing grounds; amongst others spawning areas for Atlantic cod. As result the fishing community in Hammerfest was sceptical. However, they choose to be open-minded to grasp the possibility to influence the outcome in their favour, instead of resisting this LNG development. If they would be successful, they could not only guarantee their livelihood, but their families could also benefit from a more diversified economy in times of severe community decline and depression. In other areas of Norway direct conflicts between fisheries and oil and gas activities are more likely; the narrow continental shelf of the Lofoten and Vesteralen forces both activities to operate close to each other, while in the North Sea fixed or floating, instead of 
subsea, oil drilling installations claim large restricted areas for fisheries [27]. As result fishermen in the North Sea refuse to engage in dialogue with Statoil (I-M-3), or unite with environmental NGOs in the Lofoten and Vesteralen to successfully halt oil and gas developments (I-CS-2). A strategic coalition started to develop through semi-formal meetings between Statoil and fisheries to defuse the emerging conflict about resource overlap (I-R-4).

Fisheries are, next to oil and gas, another important resource on Norway's continental shelf. Local fishermen of Hammerfest strengthened their position in this strategic coalition through representation by the national fishermen organization the Norges Fiskerlag and the national Directorate of Fisheries. Based on resources, like local knowledge and historic use, fishermen made clear demands on which a SLO could be granted. After four years of negotiations, Statoil and fishermen agreed to construct the pipeline outside important fishing grounds. The actual construction of the pipeline was determined by the Ministry of Petroleum and Energy and deviated partly from the agreement for economic reasons. This created distrust between fishermen on the one hand and Statoil and the Ministry of Petroleum and Energy on the other hand. This feeling of distrust dissolved afterwards because the pipeline was constructed under the seabed and covered with rocks and sand, in order for it to be overtrawlable (I-M-3). Remarkably the same situation was repeated when the construction of the electrical cable path deviated from the agreement between fishermen and ENI Norge, which just started oil production in 2016 from their offshore Goliat platform (I-M-1).

In the end fishermen are not compromised by the LNG plant and benefit from Hammerfest's improved quality of life, while Statoil involved fishermen early in the process to gain their SLO. Fishermen, nevertheless, emphasize the asymmetric power play during negotiations. Although fishermen felt involved by Statoil, in the end economic interest is the company's first priority. Moreover fishermen have to sacrifice fishing time at sea to engage in talks with Statoil to save their livelihood, while organizing stakeholder involvement is part of Statoil's corporate business (I-M-3). One fisherman summarized the asymmetric power play even as follows: "Ultimately it is not a decision between fishermen and Statoil, but by the Ministry of Petroleum and Energy. The national level decides and the local and regional levels have to play with (I-M-3, I-R2)".

\subsubsection{Strategic coalition: Statoil, inhabitants and Hammerfest municipality}

The strategic coalition between Statoil, local inhabitants and Hammerfest municipality emerged during public meetings in which Statoil informed local inhabitants about the state of affairs of the LNG plant and potential incidents (I-M-2; I-G-3). Initially local inhabitants were enthusiastic about the LNG plant as it might boost their economy. However, during construction, local inhabitants faced some unexpected consequences, because Hammerfest became invaded by a mobile work force of 3500 employees, which increased the population with one third. One consequence of this population increase was the occupation of tourist accommodations which harmed the tourism industry (Interview with Hammerfest Turist in [4]). Moreover local inhabitants were overwhelmed and diminished visiting bars and restaurants. This tendency can still be noticed today (I-G-3).

When the LNG plant started to operate, Statoil faced technical hurdles (I-G-1; I-G-2; I-G-3; I-M-2; I-R-4) and the public started to raise concerns about health, safety and the environment. An example was an unannounced flaring incident, which resulted in a flame of $130 \mathrm{~m}$ height which lightened up the whole city and which released more $\mathrm{CO}_{2}$ emissions than what had been permitted for the entire year (I-G-3; I-M-3). During these public meetings, Hammerfest municipality, the so-called Hammerfest Kommune, facilitated between Statoil and local inhabitants. They actively engaged in dialogue with Statoil to assure Hammerfest would benefit directly from this latter development. One major risk would be a flow of money out of the community to corporate headquarters in southern Norway. Commitment from active local organizations and Hammerfest Kommune, but also contributions from Statoil to local organizations keen on local capacity building and education like Petro Arctic, Pro Barents AS and Energi Campus Nord secured a six-fold of intended contracts with local suppliers, as estimated in 2002 [4].

The most important resource for this strategic coalition is the annual property tax of ca $€ 19$ million paid by Statoil. Hammerfest Kommune invests this tax revenue in schools, kindergarten, health care and the Arctic Culture Centre (I-G-3). Without the property tax, the situation might have been completely different (I-G-3). Despite, the revived local economy and increased quality of life, there are some economic setbacks. Initially the LNG plant would provide 2000 jobs [4], while currently only 1300 are in place [29]. Recently Statoil even tightened up contracts with the supply industry because they are able to do it cheaper themselves (I-G-1; I-G-3; I-M-4). Hammerfest Kommune is worried about employment prospects for the youth in the oil and gas industry. The local community is dependent on Statoil's financial contributions and property taxes. But, merely a transfer of money to the community by Statoil does not stimulate growth or community development, which is delegated to Hammerfest Kommune [Interview with Statoil in [4]]. Although Hammerfest Kommune is eager to implement community development and negotiated therefore with Statoil, it is dependent on respectively Norway's regulatory framework and decision-making power of Statoil, which is illustrated by the property tax and the setback in employment (I-G-3).

\subsection{Oppositional coalition}

Sámi and environmental NGOs are critical about Statoil's LNG plant. Sámi's main concern is indirect. They are afraid that increased area development and infrastructure in Hammerfest, as Arctic Energy capital, might claim areas now used for reindeer herding [4, I-G-3]. Since the Finnmark Act (2005) Sámi have acquired ownership and rights to use land and waters in Finnmark County. Property disputes and conflicts with other users are managed by the Finnmark Estate Agency, which consists of members from the Sámi Parliament and Finnmark County Council [37]. However, there is no legislation that provides Sámi with any rights to demand compensation or royalties for property claimed by development of offshore resources like oil and gas in the Barents Sea [4,38]. In addition, Sámi, unlike fisheries, are not wellintegrated in Hammerfest's community, which disadvantaged them to engage in a policy coalition with them. In the past, the Alta Controversy (1978-1982), in which Sámi protested against the building of a dam that could harm reindeer migration, created tension in Finnmark. This controversy granted Sámi power through resources like state protection and property rights under the abovementioned Finnmark Act, but Norwegians questioned the legitimacy of empowerment of Sámi which aggravated the existing tension. This figurative distance between Hammerfest's community and Sámi is strengthened by a physical distance caused by reindeer migration which urges Sámi to pursue a nomadic culture outside Hammerfest [4]. For these reasons Statoil did not perceive Sámi as primary stakeholders (I-M-2).

Although environmental NGOs Natur ug Ungdom, WWF Norway and Bellona were sceptical about the environmental performance of the LNG plant [27], Statoil got some credibility based on past negotiations. Statoil and these NGOs were already in dialogue about the Integrated Management Plan for the Barents Sea and the Lofoten Islands. This experience and the pressure of the NGOs 
resulted in the implementation of environmental best practices, such as carbon capture $\&$ storage and reduced emissions of toxic drilling fluids in the LNG plant [4]. Although NGOs furthermore lobbied the Ministry of Petroleum and Energy and the Ministry of Climate and Environment and their agencies and organized protests in Hammerfest, in the end they were rather absent in decision-making regarding the LNG plant for three reasons. First, NGOs are willing to accept a SLO for natural gas extraction, but not for oil. Second, because oil and gas are national resources and managed at the national level, NGOs lobbied the national rather than the local level. Third, the timing for the LNG plant (in tough economic times) in Hammerfest made locals feel that NGOs which strive for intangible, long-term, macro-environmental interests interfered with their right to direct economic development. As result Statoil's discourse of economic revitalization in the North coupled with oil and gas developments, prioritized at both national and local level, together with the absence of a locally-based environmental agenda, hampered national NGOs to introduce a strong sustainability discourse to influence this development at any level. However, Greenpeace Norway keeps an eye on Statoil, as they own four shares in Statoil's company which grants them access to annual meetings of Statoil.

\subsection{Marine community}

The emergence of these coalitions has affected Hammerfest's marine community significantly. Before the exploitation of LNG the marine community of Hammerfest was a local, small-scale community, consisting of a fisheries user community, while Hammerfest municipality formed the policy community. The start of LNG production by Statoil transformed the marine community dramatically. Not only became Statoil the core actor, the institutional coalition between the Norwegian State and Statoil became the most dominant coalition in this marine community. The formation of coalitions in this marine community is in the first place driven by matching discourses about revitalization of the North by the Norwegian government coupled with offshore oil and gas exploration in the Arctic by Statoil. This is further implemented through national rules like the High North Strategy and Norwegianization of oil and gas and through resources like state participation and the Norwegian regulatory system; i.e. a tax efficient system which incentivizes oil exploration and performance-based supervision of oil and gas activities which gives Statoil a lot of operational freedom. This coalition is powerful because both Statoil and the Norwegian State are at the same time part of the user and policy community. Statoil and the Norwegian State, in fact, use discourses, rules and resources of the policy community to strengthen their position as user in the marine community.

Statoil wanted to address local concerns, on the other hand, and engaged therefore in two strategic coalitions to acquire their SLO. As such Statoil became the core actor of the marine community. Local actors, from their point of view, engaged in these strategic coalitions with Statoil to ensure they would benefit from the LNG plant. By addressing concerns of fishermen and local inhabitants on respectively resource overlap and health, safety and environmental issues, Statoil received a SLO for its LNG plant. Crucial for the strategic coalition is the matching discourse of joint economic development of the community and the company. This is realized through the property tax, implemented by Norway's regulatory framework, which stimulated the local economy of Hammerfest.

The oppositional coalition did not become part of the marine community due to a mismatch in discourses regarding economic revitalization of the North coupled with oil and gas development, on the one hand, and sustainable development, based on intangible, long-term and indirect environmental concerns, on the

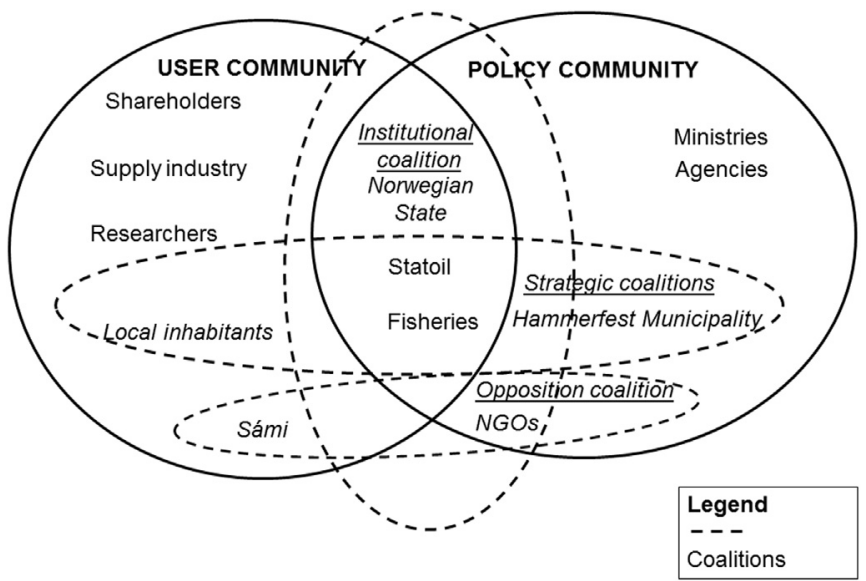

Fig. 4. Overview of the coalitions within the marine community around LNG production at Hammerfest.

other hand. This was further strengthened by the absence of local environmental NGOs with whom Sámi and nationally-based NGOs could form a coalition to mobilize resources and to introduce a sustainability discourse.

Statoil's position at the core of the marine community and at the core of two of the three coalitions (see Fig. 4), provokes the interpretation of a very dense and concentrated marine community. However, this is not correct. The strong institutional coalition, on which both the strategic and oppositional coalitions depend, is responsible for the scale mismatch between the local user and national policy community. This scale mismatch is mainly shaped by the coalitions, but also reinforced by Hammerfest's resemblance with small island developing states for the following three reasons. First, lack of resources and knowledge constrain governance capacity of the local user community to withstand the power play of the institutional coalition. As such fishermen were the only actor in the user community which had valuable resources like historic use and local knowledge, backed-up by representation of national fisheries organizations, to influence decision-making in the policy community to a certain extent. Second, Hammerfest's eagerness for employment, government revenues and the transfer of knowledge and technology, has put Statoil in a powerful position to negotiate on taxes, concessions on natural resources and investment locations. This resulted in a disproportional relationship with the local user community, as local concerns for community development were overshadowed by economic growth.

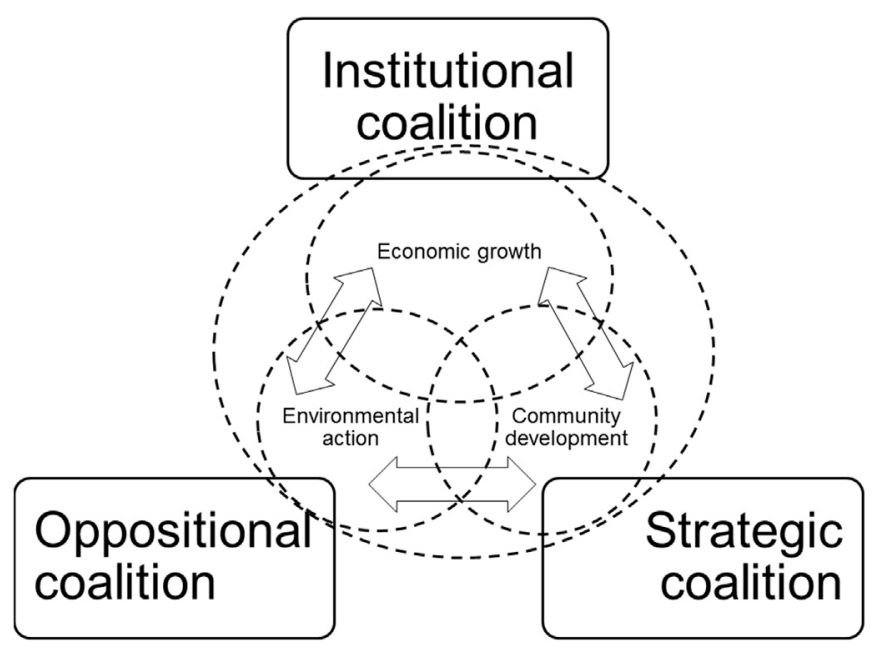

Fig. 5. Overview of coalitions in relation to the dimensions of sustainable development. 
Third, Hammerfest's isolated location from the Norwegian State in Oslo and the headquarters of Statoil in Stavanger reinforced the scale mismatch. Although Oslo-based NGOs tried to lobby the national policy community and to influence mismatching discourses of economic and sustainable development, the absence of local NGOs or a strong environmental department of Hammerfest Kommune made this unsuccessful [4]. Sámi are the closest example of a local environmental user community perspective, but they are not well integrated in Hammerfest's community. Therefore a push for environmental concerns from a local user community is largely absent. The local user community, vice versa, did not manage to get connected to the national policy community, because there is no strong cooperation between Hammerfest Kommune and the national policy community. This probably results from Hammerfest's history as small-scale marine fisheries community. Economic growth is therefore the dominant discourse in this marine community because it is pursued by both the national policy community and local user community, while community development is mainly addressed by the local user community and lacks support from the national policy community. Environmental action is not well represented by both the user and policy community and is excluded from the core of this marine community.

\section{Discussion}

How does the change from a local marine (fisheries) community to a multi-level marine (oil and gas) community affect possibilities to govern developments in a sustainable way? Despite investments in environmental best practices and early and frequent stakeholder dialogue, the dominant discourse of Statoil is economic growth, which is largely pursued by the institutional coalition (see Fig. 5). This institutional coalition provides a SLO for Statoil, mainly based on economic legitimacy and the institutionalized trust relation between Statoil and the Norwegian State.

The inclusion of environmental soundness and community development in governance regarding the LNG plant, strived for by respectively the oppositional coalition and the strategic coalitions, are however compromised by Statoil's reliance on cost-efficient and short-term conflict resolution mechanisms. Local actors perceive this as ticking the boxes rather than a long-term investment towards a SLO, based also on institutionalized trust and sociopolitical legitimacy. This can be observed in practice as contacts with fishermen, local inhabitants and NGOs faded away once an economic legitimate and interactional trust-based SLO was achieved [24, I-M-3].

Sustainable development of LNG production at Hammerfest presupposes that environmental action and community development should be addressed equally important as economic growth at both the user and policy community. This will have consequences for possibilities for sustainable governance of Hammerfest's marine community. Decision-making by Hammerfest's community should incorporate also other actors, even beyond the existing strategic and oppositional coalitions, for environmental action and community development, which might lead to a more sustainable outcome.

Policy making on behalf of the institutional coalition results in centralized decision-making regarding weighing environmental consequences and environmental monitoring. Although Norway's performance-based supervision of oil and gas provides opportunities for exploring different environmental scenarios to reach the predefined performance by the Norwegian State, so far this does not occur. Environmental scenarios or approaches to achieve a certain performance could be weighed differently by different stakeholders, but are currently mainly valued by the institutional coalition. Environmental consequences estimated by other stakeholders, especially those outside the policy arena, are less likely to be taken into account (I-CS-2). "Environmental NGOs state that there is a big gap between environmental risk assessments performed by a consultancy hired by Statoil and one conducted by them, especially regarding the worst case scenario described in the risk assessment (ICS-2)." A similar argumentation applies to environmental monitoring of the LNG plant. Performance-based supervision allows Statoil to consult national research institutes of their own choice to monitor different parts of the environment, which are not allowed to advise Statoil in policy making (I-CS-2). Monitoring results are submitted by Statoil and discussed one-on-one with the state agency at stake. As a result research is broken up across different research institutes and state agencies with different scopes and little communication between them (I-G-2; I-CS-2). In the end knowledge in this marine community is concentrated in the national policy community which compromized access to this knowledge for all stakeholders (I-G-3). In fact Statoil becomes rather powerful due to this monitoring system because it is the only actor who has a proper overview of all available knowledge.

To reduce tension between eagerness for community development in Hammerfest and centralized decision-making, Hammerfest Kommune should function more as a bridging organization, i.e. an organization designed to facilitate collaboration and knowledge coproduction among resource users, researchers and resource managers to create continuous learning [39-41]. They can make the national policy community more aware of local concerns. In relation to the local user community, Hammerfest Kommune should take over Statoil's role as organizer of stakeholder outreach by organizing public meetings. As a result Statoil, distracted and fatigued by different stakeholder demands [4], can delegate the responsibility for community development to Hammerfest Kommune. Hammerfest Kommune can build on successes and errors experienced in past public meetings organized by Statoil to address current issues, but also to be better prepared for the rather uncertain future, because decreasing oil prices have frozen Arctic oil and gas projects [42]. Although this would benefit bridging the local to national level, it does not yet deal with asymmetries in power and interests. The national policy community should be responsible to address this. However in the current Norwegian regulatory framework, a dedicated institution concerned with protecting stakeholders affected by oil and gas production is absent [4].

\section{Conclusions and recommendations}

This paper has shown that governance of LNG production by Hammerfest's marine community around LNG production rather represents economic than environmental and community development. The framework of marine communities and coalitions provides a better understanding why current governance of LNG production at Hammerfest did not move beyond economic development.

The marine community concept enlightens which actors and levels dominate the user and/or policy community, for what reasons and if and how they interact with each other. Hammerfest's marine community (both the policy and user community) on LNG production is dominated by the institutional coalition (Statoil and the Norwegian State). This powerful coalition is, apart from its actors and their coalitions, self-reinforced through the other dimensions of the policy arrangements approach, namely matching economic discourses and its implementation through resources and rules. As result policy making is largely dominated by this institutional coalition, which impedes strategic and oppositional 
coalitions to influence this process. This is strengthened by Hammerfest's similarities with small island developing states. Although the local user community tries to protect their high resource dependency by engaging in two strategic coalitions with Statoil, they lack resources and rules to influence policy-making. In the end the outcomes of both strategic coalitions are determined by resources, rules and discourses of the institutional coalition. The oppositional coalition is less successful, because their longterm environmental discourse is not pursued by other actors in the marine community. As such they cannot rely on any dimension of the policy arrangement for forming a policy coalition like sharing resources and strategies or pursuing similar discourses.

Hammerfest's marine community is characterized by the tension between economic and sustainable development and asymmetric power relations between the national institutional coalition and the rather local strategic and oppositional coalitions. Centralized decision-making power by the institutional coalition constrains knowledge sharing between actors of the institutional, strategic and oppositional coalitions and hampers effective and long-term conflict resolution in Hammerfest's marine community. To deal with environmental and community interests, within the context of centralized decision-making, the countervailing power between the institutional coalition on the one hand and the strategic and oppositional coalitions on the other, should be brought more in balance. An example of bringing both coalitions more in balance is to develop forms of ecosystem-based monitoring in which state agencies, Statoil and research institutes on the one hand and local actors on the other hand exchange knowledge and learn from each other emphasizing sustainable development. Continued public meetings, facilitated by Hammerfest Kommune, will increase attention for community development in Hammerfest, beyond the transfer of financial means by Statoil. To balance power relations among community development, the Norwegian State, should, next to its face as state participant, strengthen its face as regulator, especially to protect local communities affected by oil and gas activities, which is currently absent in Norway's regulatory framework [4].

\section{Acknowledgements}

This paper was supported by the TripleP@Sea innovation programme (KB-IV-007) of Wageningen University \& Research to contribute to smart use of marine ecosystem services providing sustainable profit of the planet for people.

\section{References}

[1] S. Patin, Environmental Impact of the Offshore Oil and Gas Industry, EcoMonitoring Publishing, East Northport, 1999.

[2] J.W. Short, Exxon Valdez/n Oil, Persists in Gulf of Alaska Beach sediments after 16 years, Environ. Sci. 41 (2007) 1245-1250, http://dx.doi.org/10.1021/ es0620033.

[3] The Arctic Council, Arctic Oil and Gas 2007, Arctic Monitoring and Assessment Programme, Oslo, 2007.

[4] M.T. Klick, The Political Economy of Corporate Social Responsibility and Community Development: A Case Study of Norwey's Snohvit Natural Gas Complex, 2009.

[5] S. Haley, L. Chartier, G. Gray, C. Meek, J. Powell, A. Andrew, Strengthening institutions for stakeholder involvement and ecosystem-based managemen in the U.S. arctic offshore, in: North by 2020. Perspect. Alaska's Chang. Soc. Syst., 2011, pp. 457-476. 〈https://iser.uaa.alaska.edu/ISER/iser/people/Shar man/strengtheninginstitutions.pdf/nhttp://press.uchicago.edu/ucp/books/ book/distributed/N/bo12373683.html/nhttp://www.iarc.uaf.edu/NX2020/ book/nhttp://www.iarc.uaf.edu/sites/default/files/nx2020/products/No〉.

[6] S. Haley, M. Galginaitis, G. Gray, C. Meek, J. Powell, J. Rosenberg, et al., Lessons from Continuity and Change in the Fourth International Polar Year, 2009.

[7] C. Pelaudeix, Governance of Arctic Offshore Oil \& Gas Activities: Multilevel Governance \& Legal Pluralism AT Stake Governance OF Arctic Offshore Oil \&
Gas Activities : Multilevel Governance \& Legal Pluralism at Stake, in: Arct. Yearb. 2015, 2015

[8] W. Ritchie, Monitoring long-term environmental change: some lessons from Sullom Voe, Shetland Islands, WMU J. Marit. Aff. 3 (2004) 193-204.

[9] P. Arbo, B. Hersoug, The globalization of the fishing industry and the case of Finnmark, Mar. Policy 21 (1997) 121-142, http://dx.doi.org/10.1016/ S0308-597X(97)83224-1.

[10] de I. Águeda Corneloup, A.P.J. Mol, Small Island developing States and International Climate Change negotiations: The power of Moral leadership, Int. Environ. Agreem. Polit. Law Econ. 14 (2014) 281-297, http://dx.doi.org/ 10.1007/s10784-013-9227-0.

[11] G. Crow, G. Allan, Community Life, an Introduction to Local Social Relations, Harvester Wheatsheaf, Hemel Hempstead, 1994.

[12] M.K. Smith, Community, Encycl. Informal Educ., 2001. 〈http://www.infed.org/ community/community.htm>.

[13] M.M. Atkinson, W.D. Coleman, Policy networks, policy communities and the problems of governance, Gov. Int. J. Policy Adm. 5 (1992) 154-180, http://dx. doi.org/10.1111/j.1468-0491.1992.tb00034.x.

[14] J. Walker, Introduction: policy communities as a global phenomena, Governance 29 (1989) 1-14.

[15] E. Sørenson, J. Torfing, Network governance and post-liberal democracy, Adm. Theory Prax. 27 (2005) 197-237, doi:Article.

[16] D. Liefferink, The Dynamics of Policy Arrangements: Turning Round the Tetrahedron, Springer, Dordrecht 2006 http://dx.doi.org/10.1007/1-40205079-8_3.

[17] K.E. Weick, The Social Psychology of Organizing, 2nd ed., Addison Wesley, New York, 1979.

[18] M. Rein, D.A. Schon, Frame-reflective policy discourse, Beleidsanalyse 4 (1986) 4-18.

[19] M.J.W. Twist, van, C.J.A.M. Termeer, Introduction to configuration approach: a process theory for societal steering, in: R. Veld, in't, L. Schaap, C.J.A.M. Termeer, M.J.W. Twist, van (Eds.), Autopoiesis Config. Theory New Approaches to Soc. Steer., Kluwer Academic Publishers, Dordrect, 1991, pp. 19-30.

[20] B. Arts, M. Buizer, Forests, discourses, Inst., . Policy Econ. 11 (2009) 340-347, http://dx.doi.org/10.1016/j.forpol.2008.10.004.

[21] M.A. Hajer, The Politics of Environmental Discourse: Ecological Modernization and the Policy, Process, Oxford University Press, Oxford, 1995.

[22] B. Arts, J.P.M. van Tatenhove, Policy and power: A conceptual framework between the "old" and "new" policy idioms, Policy Sci. 37 (2004) 339-356, http: //dx.doi.org/10.1007/s11077-005-0156-9.

[23] R.K. Yin, Case Study Research: Design and Methods, Sage publications, USA 2009 http://dx.doi.org/10.1097/FCH.0b013e31822dda9e.

[24] P. Swanborn, What Is a Case Study?, 2010. 〈http://www.sagepub.com/book sProdDesc.nav? prodId $=$ Book234703 $\rangle$.

[25] Statoil, Sustainability Report, 2013, pp. 44. 〈http://www.statoil.com/en/News AndMedia/News/2014/Pages/21Mar_AnnualReport2013.aspx>.

[26] A.B. Carroll, The pyramid of corporate social responsibility: toward the mora management of organizational stakeholders, Bus. Horiz. 34 (1991) 39-48, http://dx.doi.org/10.1016/0007-6813(91)90005-G.

[27] S.I. Pedersen, Perspectives on a Long-Term Stakeholder Dialogue, Lessons Learned from the Snohvit project-Statoil and the Fishermen's Association, Bodo, n.d.

[28] A.P.J. Mol, J.H. Mol, B.J.M. van Vliet, Suriname Schoon Genoeg? Hulpbronnengebruik En milieubescherming in een Klein Amazoneland, Van Arkel, Utrecht, 2004.

[29] Hammerfest Kommune, Hammerfest gateway to the Barents Sea, Petroleum Guide, 2012.

[30] Statoil Snohvit, 2007. 〈http://www.statoil.com/en/ouroperations/ex plorationprod/ncs/snoehvit/pages/default.aspx (accessed 19.01.15).

[31] Norwegian Petroleum Directorate, A Controlled Success, 2012. 〈http://www. npd.no/en/Publications/Norwegian-Continental-Shelf/No1-2012/A-con trolled-success/〉.

[32] Petroleum Safety Authority Norway, From Prescription to Performance in Petroleum Supervision, 2010. 〈http://www.psa.no/news/from-prescription-toperformance-in-petroleum-supervision-article6696-878.html >.

[33] Ministry of Petroleum and Energy, Act 29 November 1996, No. 72 relating to petroleum activities, Ministrt of Petroleum and Energy, Oslo, 1996.

[34] R. Boutilier, Frequently asked questions about the social licence to operate Impact Assess. Proj. Apprais. 5517 (2014) 37-41, http://dx.doi.org/10.1080/ 14615517.2014.941141.

[35] C.C.A. Smits, J.C.S. Justinussen, R.G. Bertelsen, Human capital development and a social license to operate: examples from Arctic energy in the Faroe Islands, Iceland and Greenland, Energy Res. Soc. Sci. (2016) (Forthcoming).

[36] I. Thomson, R. Boutilier, Modelling and Measuring the Social License to Operate: Fruits of a Dialogue between Theory and Practice, 2011. 〈http://sociali cense.com/publications/Modelling\%20and\%20Measuring\%20the\%20SLO.pdf〉.

[37] Norwegian Parliament, Finnmark Act (Act No. 85) Of June 17, 2005 relating to Legal Relations and Management of Land and Natural Resources in the County of Finnmark, 2005. 〈http://www.wipo.int/wipolex/en/text.jsp?file_ id $=244972\rangle$

[38] J. Vidal, Sami Reindeer Herders Battle Conservationists and Miners to Cling on to Arctic Culture, 2016. 〈http://www.theguardian.com/global-development/ 2016/feb/21/sami-people-reindeer-herders-arctic-culture).

[39] A. Carr, R. Wilkinson, Beyond participation: boundary organizations as a new space for farmers and scientists to interact, Soc. Nat. Resour. 18 (2005) 255-265, http://dx.doi.org/10.1080/08941920590908123. 
[40] L. Schultz, C. Folke, P. Olsson, Enhancing ecosystem management through social-ecological inventories: lessons from Kristianstads Vattenrike, Sweden, Environ. Conserv. 34 (2007) 140, http://dx.doi.org/10.1017/ S0376892907003876.

[41] F. Berkes, Evolution of co-management: role of knowledge generation, bridging organizations and social learning, J. Environ. Manag. 90 (2009) 1692-1702, http://dx.doi.org/10.1016/j.jenvman.2008.12.001.

[42] International Energy Agency, World Energy Outlook 2015, 2015. http://dx.doi. org/10.1787/weo-2014-en.

[43] Statoil, Major Shareholders, 2011. 〈http://www.statoil.com/annualreport2011/ en/shareholderinformation/pages/majorshareholders.aspx\#) (accessed 18.12.14).

[44] Statoil, Taxation of Statoil, 2011. 〈http://www.statoil.com/annualreport2011/ en/ouroperations/applicablelawsandregulations/pages/taxationofstatoil.aspx (accessed 28.01.15).

[45] Google maps, Hammerfest, (2015). https://www.google.nl/maps/place/Ham merfest,+Norway/@69.5434614,5.464055,4z/data=!4m2!3m1! 1s0x45c8a68a7d662d9f:0xd0cf39904de06f7b (accessed December 2, 2015). [46] Ø. Nilsen, Introduction to Melkøya plant, 2012. 